\title{
THE RELATIONS OF ELECTRIC CONDUCTIVITY WITH PHYSIOLOGICAL CHARACTERISTIC OF SOYBEAN (GLYCINE MAX (L.) MERR) SEEDS BY MATRICONDITIONING INVIGORATION TREATMENT WHEN STORED
}

\author{
Puguh Bintang Pamungkas ${ }^{1}$, Supriyono ${ }^{1}$, Edi Purwanto ${ }^{1}$ \\ ${ }^{1}$ Department of Agronomy Graduate School of Sebelas Maret University Graduate School, Ir. Sutami Street 36 A, \\ Surakarta (Solo) 57126, Indonesia
}

\begin{abstract}
PAMUNGKAS PUGUH BINTANG, SUPRIYONO, PURWANTO EDI. 2018. The Relations of Electric Conductivity with Physiological Characteristic of Soybean (Glycine Max (L.) Merr) Seeds by Matriconditioning Invigoration Treatment When Stored. Acta Universitatis Agriculturae et Silviculturae Mendelianae Brunensis, 66(4): 883-888.

Invigoration can be applied prestorage treatment, midstorage treatment, and presowing treatment. The research was aimed to determine the relations of electric conductivity with viability on soybean seed after storage. The research was conducted from August 2017 to February 2018. This research was conducted by completed randomized design with factorial 2 factor and 3 replications, i.e time of invigoration and kind of invigoration. The observed variables i.e water content (WC), seed germination (SG), index vigor (IV), electric conductivity (EC). The result showed that WC, IV and EC which is not interactions between treatment, while SG showed that it has interactions between treatment. The regression shows the influence of EC by a factor of seed physiology, which is EC-WC has a positive correlation, EC-SG and EC-IV have a negative correlation. Electric conductivity can be used as one factor in determining the viability of seed that reflects the level of meltdowns of the cell membrane. The seed with high electrolyte meltdowns (W1M4) was considered low vigor, while low electrolyte meltdowns (W3M2) was considered high vigor.
\end{abstract}

Keywords: electric conductivity, invigoration, matriconditioning, soybeans

\section{INTRODUCTION}

Seed Storage is one of the important post-harvest handlings in maintaining the quality. One of the disadvantages of soybeans production is storage problem because of the rapid deterioration process, thus reducing the provision of good seeds. According to Copeland, et al.(1985) factors that affect the viability of seeds when stored are intrinsic factors (genetical, seed germination and vigor), and extrinsic factors (seed's package, gas content, temperature, and storage humidity).

One of the efforts that can be done to increase the quality of seeds (seed's viability and vigor) is by invigoration technique. One of the seed invigoration treatment that is proven effective is matriconditioning, where that is a controlled seed hydration treatment using moist media dominated by matrix strength to improve seed's growth, such as charcoal husk and sawdust (Khan et al., 1990).

Seed Invigoration can be done at the pre-storage time, mid storage time, or presowing time, but seed invigoration of presowing time and mid storage time is deemed more effective to increase the viability and germination of seeds compared to the invigoration of pre-storage time, (Basu 1994). 
Invigoration technique is proven effective to increase the quality of seeds, Ilyas et al. (2000 and 2002); Ilyas. 2006, also reported that matriconditioning treatment using sawdust can increase the quality of chilli seeds and long beans.

This research was aimed to determine the relations of electric conductivity with viability on soybean seed after storage.

\section{MATERIALS AND METHODS}

This research was conducted between August 2017-February 2018 in Agrotechnology and Chemical laboratory of Mercu Buana University of Yogyakarta. Equipment used are conductivity meter $\mu$ Siemens; plastic; oil paper; scrap paper; analytic scale; sealer; germinator; oven; stationery; camera. Materials used are $5 \mathrm{~kg}$ soybean seeds Anjasmara variety from Institution of Food Crops And Horticulture Seed Development (BPPTPH) Wonosari, Special Region of Yogyakarta, Indonesia; charcoal husk; ash husk; and sawdust.

The research is conducted using completed randomized design with factorial 2 factor and 3 replications, which are time of invigoration and kind of invigoration. The first factor of invigoration administration consists of 3 levels, which are $\mathrm{Wl}=$ prestorage $\left(1^{\text {st }}\right.$ month of storage); $\mathrm{W} 2=$ midstorage $\left(4^{\text {th }}\right.$ month storage $) ; \mathrm{W} 3=$ presowing ( $7^{\text {th }}$ month of storage). The second factor of matriconditioning invigoration treatment consists of 4 levels, which are $\mathrm{Ml}=$ without invigoration (control); M2 = moist charcoal husk; M3 = moist ash husk; M4 = moist sawdust.

Seed treatment using matriconditioning employs 9:6:7 ratio, which is the ration between seed:media:water, $9 \mathrm{~g}$ of seeds are mixed with $6 \mathrm{ml}$ water and $7 \mathrm{~g}$ matriconditioning media (charcoal husk/ash husk/sawdust) and incubated for 12 hours then dried and stored at room temperature $\pm 25^{\circ} \mathrm{C}$, then given invigoration treatment based on the material and time that has been determined.

The test is done in the early and late storage time. In early time the test consists of water content, seed germination and vigorindexes. Whilst in the late time the test consist of water content, seed germination, vigor indexes, and electric conductivity.
The data is analyzed using Analysis of Variance (ANOVA) on the level of $5 \%$. If the treatment has real effects, the test will be continued by Duncan's New Multiple Range Test (DMRT) on the level of $5 \%$.

\section{RESULTS AND DISCUSSION}

\section{Water Content}

The result of analysis with a variation shows that there is no interaction between treatments, while early storage water content shows significant differences towards purata. The highest water content in W1M3 treatment, while the lowest water content in W3M2 treatment (Tab. I).

According to Suhartanto (2013), the deterioration of seeds is parallel to the increase of seed's water content, thus water content is a factor that affects seed viability.

According to the research's results, there is an escalation of the water content of the seed for 5 months storage periods, where water content (WC) in the early storage is on average of $10.6 \%$ and in the late storage is in range $12.35-13.50 \%$. That is similar with statement of Begum et al.(2013) where during storage, carbohydrate and protein content decreased, while water content and electrical conductivity increased.

According to Purwanti (2004), storage temperature has a role in maintaining soybean seed viability while in storage. At the high temperature, the respiration goes faster compared to at the low temperature, according to Sukarman and Muhadjir (1993) respiration products in the form of $\mathrm{H}_{2} \mathrm{O}$ and $\mathrm{CO}_{2}$ can cause the escalation of WC.

The relation between water content and seed storability, as stated in Harrington's principle (1972), which is for every one percent decreases of the seed water content, the seed storability is doubled. On the other hand, for every one percent increase of the seed water content, the seed storability is halved (Copeland and McDonald, 1985).

\section{Seed Germination}

The result of analysis with a variation shows that there is an interaction between treatments. Early seed germination also shows that there are significant differences with purata. The highest seed

I: Purata of soybean seed water content after being given invigoration treatment when in storage

\begin{tabular}{|c|c|c|c|c|c|}
\hline \multirow{2}{*}{$\begin{array}{c}\text { Time of } \\
\text { invigoration }\end{array}$} & \multicolumn{4}{|c|}{ Kind of invigoration } & \multirow{2}{*}{ Purata } \\
\hline & M1 & M2 & M3 & M4 & \\
\hline \multicolumn{6}{|c|}{ Water content (\%) } \\
\hline W1 & 12.5 & 13.2 & 13.5 & 13.1 & $13.1 \mathrm{p}$ \\
\hline W2 & 12.8 & 13.0 & 12.8 & 13.6 & $13.1 \mathrm{p}$ \\
\hline W3 & 12.7 & 12.3 & 12.7 & 12.8 & $12.6 \mathrm{p}$ \\
\hline Purata & $12.7 \mathrm{a}$ & $12.9 \mathrm{a}$ & $13.0 \mathrm{a}$ & $13.2 \mathrm{a}$ & $12.9 \mathrm{~B}$ \\
\hline Initial & & & & & $10.60 \mathrm{~A}$ \\
\hline
\end{tabular}

Explanation: Purata values that are followed by the same letter shows that there are no differences according to DMRT 5\%. 
germination in W3M2 treatment, while lowest seed germination in W1M3, W1M4, and W2M4 (Table 2).

Based on the result of the conducted research, there isa decreasing number of seeds germination in soybean seed, where seed germination (SG) in the early storage time is $81 \%$ and in late storage time is $61.33 \%-75.33 \%$, these numbers indicate that there is a deterioration of physiological quality of the stored soybean seeds.

The declining of SG number of soybean seeds while in storage indicates the decline of the physiological quality. This statement is true according to Copeland and McDonald (1995) which state that the deterioration of seeds physiological quality occurs gradually and cumulatively due to the changes in the seed physiology and biochemistry.

The decreasing percentage of soybean seeds SG when stored occurs because there is an uncontrollable temperature of the storage room. According to Purwanti (2004), storage room temperature which is higher than $20^{\circ} \mathrm{C}$ is unsuitable for soybean seeds, in a room with a temperature of $30{ }^{\circ} \mathrm{C}$, seeds with initially high seed germination will decrease to $0 \%$ in 6 months.

Besides due to the environmental factor, the decreasing of SG number also caused by a genetic factor from each variety, Copeland and McDonald (1995) state that the internal factors that have a role in seed viability when stored are genetic, germination and vigor, skin condition and seed initial water content.

In accordance with notion stated by Kartono (2004), factors that can affect soybean seed germination when stored are the quality and germination of seed before stored; seed's water content; storage humidity; storage temperature; pest and disease in the storage; and storage time.

\section{Vigor Indexes}

The result of analysis with a variation shows that there is no interaction between treatments, while early storage vigor indexes shows significant differences towards purata. The highest Vigor Index in W3M2 treatment while the lowest vigor index in the W1M4 treatment (Tab. 3).

According to the research results, there is a decline in soybean seed vigor index (VI), where the number of vigor index at initial storage is 10.02 and at the end of storage is 7.22-9.34 in range.

Vigor Index (VI) is the number of normal seeds at the first count which is the fourth day of SG test (Copeland and McDonald, 1995). High VI values show that the seed will sprouts faster, thus categorized as strong vigor, and vice versa. The decline of soybean seed SG is followed by the value of VI while in storage time.

The concept of seed viability which consists of VI and SG is explained by Steinbauer-Sadjad which developed into Steinbauer-Sadjad Concept (Sadjad, 1989). The concept of seed viability periods is divided into 3 parts, Period I, II, and III.

Period I is energy storing period. This period is the period of seed growth and development starting from anthesis until the seed is mature physiologically. Period II is energy transit and energy release period, the value of viability is maintained in this period. Periode III is the end of seed storing period, this period is also the critical period because seeds have to show their quality in the field.

II: Purata of soybean seed germination after being given invigoration treatment when in storage.

\begin{tabular}{|c|c|c|c|c|c|}
\hline \multirow{2}{*}{$\begin{array}{c}\text { Time of } \\
\text { invigoration }\end{array}$} & \multicolumn{4}{|c|}{ Kind of invigoration } & \multirow{2}{*}{ Purata } \\
\hline & M1 & M2 & M3 & M4 & \\
\hline \multicolumn{6}{|c|}{ Seed germination (\%) } \\
\hline W1 & $71.3 \mathrm{~B}$ & $64.0 \mathrm{EF}$ & $61.3 \mathrm{~F}$ & $61.3 \mathrm{~F}$ & 64.5 \\
\hline W2 & $70.7 \mathrm{BC}$ & $62.7 \mathrm{EF}$ & $64.7 \mathrm{DE}$ & $61.3 \mathrm{~F}$ & 64.8 \\
\hline W3 & $71.3 \mathrm{~B}$ & $75.3 \mathrm{~A}$ & $68.0 \mathrm{BC}$ & 67.3 CD & 70.5 \\
\hline Purata & 71.1 & 67.3 & 64.7 & 63.3 & $66.6 \mathrm{~B}$ \\
\hline Initial & & & & & $81 \mathrm{~A}$ \\
\hline
\end{tabular}

Explanation: Purata values that are followed by the same letter shows that there are no differences according to DMRT 5\%.

III: Purata of vigor indexes of soybean seed after being given an invigoration treatment when in storage

\begin{tabular}{|c|c|c|c|c|c|}
\hline \multirow{2}{*}{$\begin{array}{c}\text { Time of } \\
\text { invigoration }\end{array}$} & \multicolumn{4}{|c|}{ Kind of invigoration } & \multirow{2}{*}{ Purata } \\
\hline & M1 & M2 & M3 & M4 & \\
\hline \multicolumn{6}{|c|}{ Vigor indexes } \\
\hline W1 & 8.3 & 7.5 & 7.9 & 7.2 & $7.2 \mathrm{Q}$ \\
\hline W2 & 8.4 & 7.9 & 8.1 & 7.9 & $8.1 \mathrm{Q}$ \\
\hline W3 & 9.2 & 9.3 & 8.3 & 8.2 & $8.8 \mathrm{P}$ \\
\hline Purata & $8.6 \mathrm{~A}$ & $8.3 \mathrm{AB}$ & $8.1 \mathrm{~B}$ & $7.7 \mathrm{~B}$ & $8.2 \mathrm{~B}$ \\
\hline Initial & & & & & $10.02 \mathrm{~A}$ \\
\hline
\end{tabular}

Explanation: Purata values that are followed by the same letter shows that there are no differences according to DMRT 5\%. 
IV: Purata of EC of soybean seeds after being given an invigoration treatment when in storage.

\begin{tabular}{lccccc}
\hline \multirow{2}{*}{$\begin{array}{c}\text { Time of } \\
\text { invigoration }\end{array}$} & \multicolumn{4}{c}{ Kind of invigoration } & \multirow{2}{*}{ Purata } \\
\cline { 2 - 4 } & $\mathbf{M 1}$ & \multicolumn{1}{c}{ M2 } & M3 & M4 & \\
\hline W1 & 40.0 & 46.9 & 48.3 & 50.8 & $46.5 \mathrm{P}$ \\
W2 & 39.3 & 43.7 & 44.2 & 46.3 & $43.4 \mathrm{Q}$ \\
W3 & 38.1 & 37.4 & 43.9 & 45.2 & $41.2 \mathrm{R}$ \\
Purata & $39.1 \mathrm{D}$ & $42.7 \mathrm{C}$ & $45.5 \mathrm{~B}$ & $47.5 \mathrm{~A}$ & 43.7 \\
\hline
\end{tabular}

Explanation: Purata values that are followed by the same letter shows that there are no differences according to DMRT 5\%.

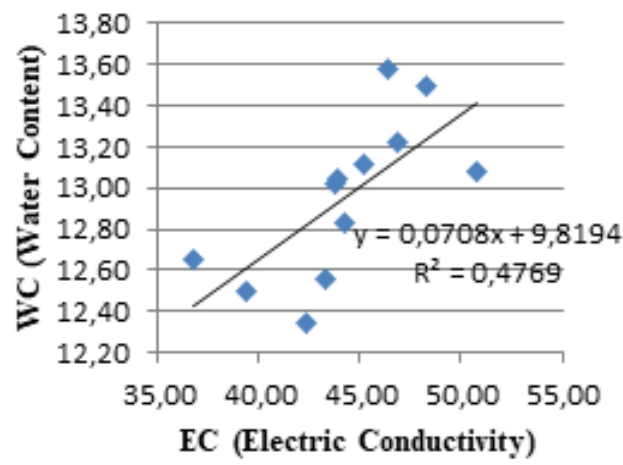

1: Regression line between EC-WC

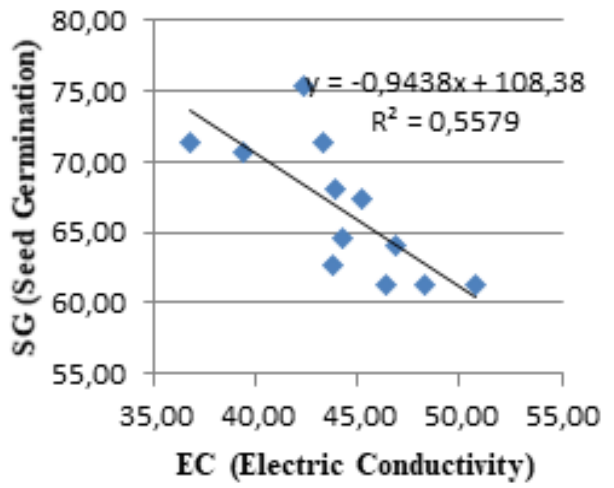

2: Regression line between EC-SG

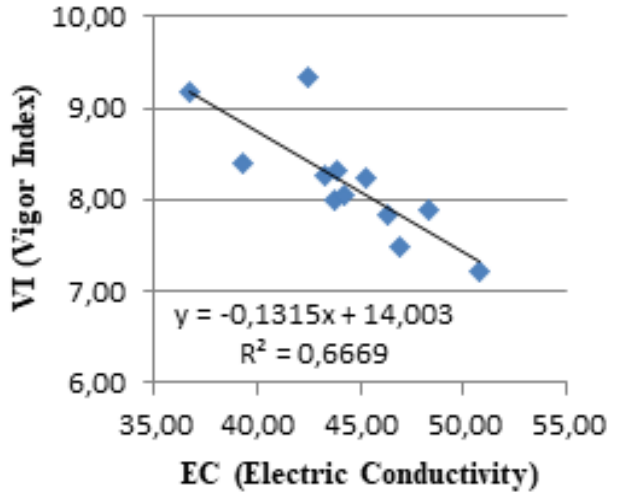

3: Regression line between EC-VI 


\section{Electric Conductivity}

The result of analysis with a variation shows that there is no interaction between treatments, while the treatment shows that there is a difference. The highest EC in W1M4 treatments while the lowest EC in W3M2 treatment (Tab. VI).

Electric Conductivity is one of the determining characters of seeds viability which reflected the level of cell membrane leakage. The seed which has low electrolyte leakage is deemed to have a high vigor, and vice versa (ISTA, 2005).

According to the research results, EC value from each treatment is fluctuating in nature, where EC is in between of 37.37 to $50.80 \mu \mathrm{S} \mathrm{cm}^{-1} \mathrm{~g}^{-1}$, but EC of seeds is paralel with period of storage.

In early research, EC behavior shows paralel with period of storage According Beedi S et al.(2018) and Dias et al.(2004) seeds with a high EC value is possible because the seeds are damage in cell membrane, and that causing electrolyte leakage and releasing a solutes into outside of the seed, such as sugars, amino acids, fatty acids, proteins, enzymes and organic ions $\left(\mathrm{K}^{+}, \mathrm{Ca}^{2+}, \mathrm{Mg}^{2+}, \mathrm{Na}^{+}\right.$and $\left.\mathrm{Mn}^{2+}\right)$. (Noviana et al., 2017; Naguib et al., 2011; Nabila et al., 2016; Beedi S et al., 2018).

\section{The Relation of EC with Seed Physiology Characteristics.}

To know the effect of invigoration administration time (W) and invigoration type (M) toward EC sensitivity in detecting seed's vigor related to the quality of the seed, regression analysis after storage is conducted.

The equation of regression line stated the relation between EC (x-axis) with WC, SG, VI (y-axis).
Coefficient correlation numbers show that $y$ characteristic is affected by $\mathrm{x}$ characteristics as much as the value of the correlation number. Regression lines (figures 1 to 3 ) show the relation between EC with other characteristics from WC, SG, and VI.

Fig. 1 shows the effect of EC towards WC. As shown from the figure, it can be known that EC-WC relation has a positifve slope which means that the higher the EC the WC also become higher. WC variety also shown by correlation coefficient value (r), correlation coefficient in this research is of 0.690 which means that $69.0 \%$ of WC variety is caused by the EC while the rest is caused by another factors.

Fig. 2 shows the effect of EC towards SG. As can be seen from the figure that there is a pattern of EC-SG, the pattern of EC-SG relation has a negative slope which means the higher the EC the lower the SG. SG variety also shown by correlation coefficient value (r), correlation coefficient in this research is of -0.746 which means that $74.6 \%$ of SG variety is caused by EC while the rest is caused by other factors.

Fig. 3 shows the effect of EC towards VI. As can be seen from the figure, it can be seen that EC-VI relation has a negative slope which means that the higher the EC the lower the VI. VI variety also shown by correlation coefficient value (r), correlation coefficient in this research is of -0.816 which means that $81.6 \%$ of VI variety is caused by EC while the rest is caused by another factors.

This results is similar with research was conducted Balachander et al.(2018) and Mahawar dkk (2018), the results showed that increase EC value followed by an increase in water content and decrease seed germination value, viability of seeds tested by TZ, protein and oil content, this is because the seeds has high electrolyte leakage.

\section{CONCLUSION}

Electric Conductivity can be used as one of the determining characteristics of seed viability, which reflected the level of cell membrane leakage. Seed that has high electrolyte leakage (W1M4) is deemed to have low vigor, while seed that has low electrolyte leakage (W3M2) is deemed to have a high vigor. In this research, the value of EC is between $36.40 \mathrm{up}$ to $52.30 \mu \mathrm{S} \mathrm{cm}^{-1} \mathrm{~g}^{-1}$. Furthermore, EC has a negative correlation with SG and VI characteristics which signifies that the higher the value of SG and VI thus making the EC lower, while compared to WC characteristic, EC has a positive correlation which signifies that the higher the value of KA thus making the EC value higher.

\section{REFERENCES}

BALACHANDER B. S., HARSHIKA NETHA, N. and DALVI, D. G. 2018. Effect of Genotypes and Containers on Physiological and Biochemical Changes during Storage of Soybean seed (Glycine max L. Merrill). Int. J. Curr. Microbiol. App. Sci., 6(Special Issue): 1836-1851.

BASU, R. N. 1994. An Appraisal of Research on Wet and Dry Physiological Seed Treatments and Their Applicability With Special Reference to Tropical and Subtropical Countries. Seed Sci. Tech., 22: 107-126.

BEEDI, S., MACHA, S. I., BASAVE GOWDA, B., SAVITHA, A. S. and KURNALLIKAR, V. 2018. Effect of Seed Priming on Germination Percentage, Shoot Length, Root Length, Seedling Vigour Index, Moisture Content And Electrical Conductivity In Storage Of Kabuli chickpea cv., MNK-1 (Cicer arietinum L.). Journal of Pharmacognosy and Phytochemistry, 7(1): 2005-2010.

BEGUM, A. J., JERLIN, R. and JAYANTHI, M. 2013. Seed Quality Changes During Storage Of Oil Seeds-A Review. International Journal of Scientific Research, 2: 1-2.

COPELAND, L. O. and MC DONALD, M. B. 1985. Principle of Seed Science and Technology. New York: Chapman \& all Publishing. 
COPELAND, L. O. and MC DONALD, M. B. 1995. Principle of Seed Science and Technology. New York: Chapman \& Hall Publishing.

DIAS, D. C. F. S., FREITAS, R. A., DIAS, L. A. S. and OLIVERA, M. G. A. 2004. Storage Potential Of Cotton Seeds Predicted By Vigour Tests And Biochemical Assays. In: 27th ISTA Congress, Budapest, Hungary, 2004.

HARRINGTON, J. F. 1972. Seed Storage and Longevity. In: KOZLOWSKI, T. T. (Eds.). Seed Biology. Vol III. New York.: Acad. Press.

INTERNATIONAL SEED TESTING ASSOCIATION. 2005. Annexe to Chapter 15: Seed Vigour Testing. In: International Rules for Seed Testing. $5^{\text {th }}$ Edition. ISTA.

ILYAS, S., HASAN, A., SIREGAR U. J. and SUDARSONO. 2000. Matriconditioning Improve yard-long Bean Seed Quality. In: Third International Crop Science Congress. Hamburg, 17-22 August 2000.

ILYAS, S., SUTARIATI, G. A., SUWARNO, F. C. and SUDARSONO. 2002. Matriconditioning Improve Hot Pepper Seed Quality. Seed Technology, 24(1): 65-75.

ILYAS, S. 2006. Seed Treatment Using Matriconditioning To Improve Vegetable Seed Quality. Bul. Agron., 34(2): 124-132.

KARTONO. 2004. Soybean Seeds Wilis Variety Technique At Water Content And Different Storage Temperature. Bulletin of Agricultural Engineeing, 9: 79-82.

KHAN, A. A., MIURA, H., PRUSINSKI, J. and ILYAS, S. 1990. Matriconditioning of Seed to Improve Performance. In: Proceedings of The Symposium on Stand Establishment of Horticultural Crops. Minnesota, 14-15 April 1990, pp. 19-40.

MAHAWAR, M. K., SAMUEL, D. V. K., SINHA, J. P. and JALGAONKAR, K. 2018. Moisture-Dependent Physical And Physiological Properties Of Accelerated Aged Pea (Pisum sativum L.) Seeds. Current Science, 114(4): 909-915.

NABILA, S. M., AMIN, A. K. M. R., ISLAM, O., HAQUE, N. and ACHAKZAI, A. K. K. 2016. Effect Of Storage Containers On The Quality Of Wheat Seed At Ambient Storage Condition. Am-Eurasian J. Agric. Environ. Sci., 16(2): 402-409.

NAGUIB, N. A., MOHAMED, E. A. I. and EL- AIDY, N. A., 2011. Effect Of Storage Period And Packaging Material On Wheat (Triticum aestivum L.) Seed Viability And Quality. Egypt. J. Agric. Res., 89: 1481-1497.

NOVIANA, I., DIRATMAJA, A., QADIR, A. and DAN FAIZA, C. S. 2017. Estimation Deterioration of Soybean (Glycine max L. Merr) Seeds During Storage. Agros Agriculture Journal, 19(1): 1-12.

PURWANTI SETYASTUTI. 2004. Study of Room Temperature on Quality of Black and Yellow Soybean Seed. Journal Agriculture of Science, 11(1): 22-23.

SADJAD, S. 1989. Steinbauer-Sadjad Concept as the Foundation of Indonesian Seed Mathematics. Scientific Oration. Bogor Agricultural University.

SUHARTANTO, M. R. 2013. Basic of Seed Science And Technology. Bogor: Press of Bogor Agricultural University.

SUKARMAN, MUHADJIR, M. F. 1993. The Viability of Soybean Seeds In Initial Water Content and Different Storage Methods. Agricultural Research, 13:31-34. 